\title{
Management is not a Game: The Effects of Strategy and Structural Changes in the Competitiveness of Football Clubs
}

\author{
Diego Figueiredo ${ }^{\dagger}$ \\ Universidade Federal de Minas Gerais - UFMG \\ Luis Henrique dos Santos Figueiredo ${ }^{\mathbf{2}}$ \\ Universidade Federal de Minas Gerais - UFMG
}

\begin{abstract}
This article analyzes the use of strategy, structure and professionalization to improve the long-term competitiveness of sport organizations. The case study contemplates two of the top ten Brazilian football clubs using qualitative data from 21 interviews with their upper management, and a documentary research of secondary data. The results indicate that similar structural changes and professionalization processes have different implications for the clubs, with distinct contributions to their growth and competitiveness. The research presents evidence that both the formulation of the strategy and the way it is implemented are determinant in conciliating sports and financial objectives with the responses to internal and external contingencies, implementing organizational changes to benefit the performance of the club on-field and off-field.
\end{abstract}

Keywords: Professionalization; Strategy; Sports Management; Competitiveness.

*Author for correspondence:

$\dagger \mathrm{PhD}$ candidate in Business Administration UFMG/FACE/CEPEAD

Av. Presidente Antônio Carlos, 6627 - Sala

4012 Pampulha - Belo Horizonte, MG, Brazil CEP: 31270-901

E-mail: dfigueiredoav@gmail.com
$\Omega$ Master's candidate in Business Administration UFMG/FACE/CEPEAD

Av. Presidente Antônio Carlos, 6627 - Sala 4012

Pampulha - Belo Horizonte, MG, Brazil CEP: 31270-901

E-mail: luis.hsfigueiredo@gmail.com

Note from the Editor: The article was accepted by Bruno Felix. 


\section{INTRODUCTION}

$\mathrm{T}$

he strategic management of football clubs in Brazil has become as challenging as winning football championships. The achievement of sustainable competitiveness increasingly relies on clubs' organizational restructuring and professionalization, as much as team building and skilled players are key to superior performance on the field. Between 2003 and 2014, the revenue of the 20 biggest Brazilian teams grew 388\% (SILVA, 2016; SOMOGGI, 2015) and despite this growth, their total debt increased 530\% during the same period, reaching BRL 6.2 billion, the equivalent to two years of their total revenue. Moreover, the combined loss of these clubs corresponded to 19\% of their 2014 total income (SILVA, 2015; SOMOGGI, 2015). Strategy, according to Chandler, is "the determination of the basic long-term goals and objectives of an enterprise and the adoption of courses of action and the allocation of resources necessary for carrying out these goals" (CHANDLER, 1962, p.15-16). When confronting the past decade's financial performance of football clubs with this early definition of strategy, we may infer that their general managers rather choose to deal with the following season's championship sportive priorities, no matter the cost. In fact, Brazilian football clubs are nonprofit legal entities and their main objective is analogous to that of most European football clubs: the maximization of playing success instead of profits (GARCIA-del-BARRIO; SZYMANSKI, 2009; SLOANE, 2015). However, in Europe the clubs are subject to a break-even constraint (MORROW, 2014), which is not the case in Brazil yet. Apart from the risk of insolvency, the collateral effect of this practice is that these 20 clubs have a renegotiated tax liability of BRL 2.1 billion in 2014, 34\% of their total debts.

Notwithstanding the importance of the football industry in Brazil, local scholars have paid little attention to empirical research about strategic choice to match environmental circumstances to the organization and competitiveness of football clubs. The first decade of the $21^{\text {st }}$ century was marked by a debate in relation to the clubs poor sportive and financial performance (VALENTE; SERAFIM, 2006; ZOUAIN; ALVES; PIERANTI, 2006), new laws that imposed restrictions regarding football players' registration (SOUZA; ANGELO, 2005), as well as the need of management professionalization (AZEVEDO; REBELLO, 2002; LEONCINI; SILVA, 2005). As a corollary of such debate, researchers turned their attention to the impacts and opportunities of football commercialism (GONÇALVES; CARVALHO, 2006) and globalization (RIBEIRO, 2007), the emergence of sport marketing (AREIAS, 2007; ALBINO et al., 2009) as well as the need of business-like management of clubs (AIDAR; LEONCINI, 2002; GONÇALVES; SILVA, 2007; RODRIGUES; SILVA, 2009).

The past five years, a period when the financial situation of the majority of football clubs got worse, has provided a context in which studies were conducted about their financial efficiency (NASCIMENTO et al., 2015). To a certain extent, the local scholar debate during this period 
reflected similar concerns to those from the international academy about football. The arrival of the new century has brought new opportunities and challenges for football clubs as a global sport, leading academic approaches to study football as a business (HAMIL; MICHIE; OUGHTON, 1999; SLOANE, 2015) that required a particular strategy (GRUNDY, 2004, SHILBURY; FERKINS, 2011), the development of an international marketing approach (DESBORDES, 2007; RATTEN, 2016), accountability and corporate governance (DIMITROPOULOS, 2014; RADIC, 2014), as well as a regulatory review (MORROW, 2014).

The purpose of this study is to investigate two of the top ten Brazilian clubs, Cruzeiro Esporte Clube and Sport Club Internacional, to determine their responses to internal and external contingencies in regards to organizational, sportive and financial performance, between 2003 and 2012. This paper demonstrates the impact of the changing football environment on these clubs' management practice and, more specifically, how strategy, the club's structure and professionalization were used to improve overall long-term competitiveness, on-field and off-field.

\section{LITERATURE REVIEW}

\section{STRATEGY AND COMPETITIVE ADVANTAGE}

The football clubs in Brazil do not count neither with academic approaches nor with local successful benchmarks as models on how to overcome their financial crisis and achieve superior long-term performance. Even though foreign successful team cases (GERRARD, 2005) or the analysis of international football teams/leagues (GARCIA-del-BARRIO; SZYMANSKI, 2009) may be useful references to assess local clubs' strategy and professionalization practices, their contribution might be limited due to relevant asymmetries between local and foreign markets. Therefore, our option in this empirical study is to draw on traditional works on strategic management research to look for insights that might help its investigation.

The strategy of a firm aligns its strengths and weaknesses to environmental opportunities and threats, under changing circumstances, to achieve superior and sustainable performance (PORTER, 1991). While many studies about the sources of sustained competitive advantage focused their attention on the analysis of environmental conditions that may favor superior performance (PORTER, 1980,1991), others examine the firms' resources and their link with sustained competitive advantage (WERNERFELT, 1984; BARNEY, 1991). A competitive advantage exists when the firm implements a value creating strategy, which differs from those developed by its competitors; it is a sustained competitive advantage, even if not lasting forever, when the competitors are unable to duplicate the benefits of this strategy (BARNEY, 1991). The concept of value chain introduced by Porter (1991) refers to the firm's potential resource-based advantages. The resource-based view of the firm approach developed by Barney (1991) advances the value chain logic further and proposes 
which are the attributes of isolated value chain resources that make them sources of sustained competitive advantage: they are valuable, rare, imperfectly imitable, and non-substitutable (BARNEY, 1995). The author states that to realize the firm's competitive advantage potential, the firm must be organized to fully use and benefit from its resources and capabilities. Even though the various components of a firm's organization have a limited ability to generate superior performance in isolation, when combined with other firm's resources and capabilities they can enable it to achieve its full competitive advantage (BARNEY, 1995).

Barney's approach corroborates Chandler (1962)'s statement that organizational structure follows strategy, meaning that different matches between strategy and structure have different effects on a firm's performance. However, the growing interest in competitive outcomes of organizational development have leaded some scholars to study the processes of strategy implementation separately from the firm's content of strategy or from its competitive context, which is inappropriate according to the developments of resource-based view suggestions (BARNEY, 1995). Another call to strategy academics and practitioners worth mentioning is the one from Whittington (1996) to the approach focused on strategy as a social "practice", on how strategists really interact. The "practice" approach is based on insights from the processes that allow organizations to acknowledge the need for strategic change and how to achieve it, but it is concerned with how the practitioners at the management level "strategize". Instead of being concerned with the core competences of the organization, the practice perspective is concerned with the practical competence of the manager as a strategist (WHITTINGTON, 1996). In a parallel work, Mintzberg, Ahlstrand and Lampel (2005) reviewed the vast literature of strategic management and identified ten "schools" of thought regarding the strategy-formation process. Each one of them views strategy from a different managerial perspective of strategy formation process. To maintain the study's focus, the article draws on some insights provided by the entrepreneurial and the configuration approaches. The Entrepreneurial School focuses on the person who leads the organization. It is concerned with the leader's vision rather than their team's perceptions, with his/her intuition and mental vision about the future path that the organization should follow. The entrepreneurial strategy has paternalistic traits, centralizes authority and transforms the leader into an individual with "superpowers". The Configuration School, distinctively, pays attention to the different strategy/structure patterns that allow the organization to evolve from stability periods to stages of transformation leading to a new configuration of its structure in search of a fit to the changing environment.

\section{STRUCTURE}

Donaldson (1999) states that the classical theory concentrates the first essays and works about organizational structure, based on the search for the best way to organize a firm. He highlights the 
incorporation of changes in organizational structures by hierarchical decentralization and work abstraction. Chandler (1962) contributes to these studies by stating that the structure is not just a choice of a more efficient option, but a sketch, i.e., a configuration of resources and internal processes related to factors surrounding the organization and the goals set by the organizational strategy. The author develops his argument by defining the structure as reactive. Through the projected strategy, problems and internal obstacles take place and affect the organizational performance. Therefore, it is necessary to adopt an appropriate structure to regain performance. Although structural factors influence decision-making, Chandler (1962) states that the structure is contingent to the expansion and growth strategy established by the top management. The contingency theories (CHANDLER, 1962; LAWRENCE; LORSCH, 1967) study the organization behavior based on the idea that either the intra-organizational context or the environment puts pressure on the organization and requires its structure to adapt in the long run. The notion of contingency adjustment to structure is based on the idea that a misfit of structure and contingency leads to low performance that creates pressure for change to recover structure-contingency fit (DONALDSON, 1999). For the purposes of this article, a standard organization structure has five parts: 1) the strategic apex consists of the upper management and its personal staff; 2) the middle line comprises the managers responsible for the operations; 3) the operating core includes all employees in charge of the club's services; 4) the technostructure "consists of those analysts, out of the formal 'line' structure, who apply analytic techniques to the design and maintenance of the structure and to the adaptation of the organization to its environment"; 5) the support staff provides indirect support to the various organizational teams - legal counsel, public relations, quality auditing, etc. (MINTZBERG, 1995, p. 323).

\section{PROFESSIONALIZATION}

The term professionalization refers to organizational changes introduced in football clubs to implement a more business-like approach to its management and operations. Applying the concept of Shilbury and Ferkins (2011, p.108) to the football industry, professionalization means the "transition from an amateur, volunteer-driven pastime to a more business-like sector". It has to do with:

[...] "the change experienced as a result of the influx of full-time, managerial businesslike professionals into what have been traditionally volunteer-run organizations...

Changes in this regard are caused by, and are the product of, professionals entering sport organizations who introduce new managerial practices, decision-making processes, programs and/or policies." (DOWLING et al., 2014, p.522).

The goal of this study is to investigate its influence on clubs management and the way they strategize the development of their organizations. How do strategy, structure and professionalization 
contribute to improving the long-term competitiveness of football clubs? The empirical research on this question will help to understand the actual implications of internal resources and capabilities development and to which extent they may help clubs to benefit from market opportunities and constraints.

\section{METHODS}

This study adopts a qualitative research method of exploratory and descriptive character implemented through case studies. The professionalization of football clubs' management in Brazil is a relatively recent phenomenon with scarce empirical research. Therefore, the qualitative approach is well suited because it allows the researcher to explore in depth the complex relationships and facts involved in a particular case (FLICK, 2004). It uses the descriptive method due to its flexibility and integration with the phenomenon under analysis, giving the researcher greater freedom throughout the study's development and in the analysis of the variables involved in the case. According to Yin (2001), it also considers a greater number of evidence than other research in strategies do, preserving the characteristics and specificities of a particular event, analyzed within its own context.

In March 26, 2001, the article of the Pelé Law that abolished the limitation of player's mobility became effective and raised a concern about unbalanced competitiveness among clubs (SOUZA; ANGELO, 2005). In 2001, Cruzeiro ended the Brazilian football championship in the $21^{\text {st }}$ position. In the following year, 2002, it was Internacional's turn to finish the championship in the $20^{\text {th }}$ position. Both clubs, at the end of those two seasons, were few positions above relegation to the "B" division of Brazilian football. The study covers the ten-year period between 2003 and 2012, and captures the changes introduced by the abolition of the transfer system, as well as other structural modifications in the football market. To triangulate the data collected through interviews, a primary and secondary documental research used books, documents, collections, magazines, newspapers, editorials and audited financial statements directly from the clubs. Afterwards, presidents and vice presidents, directors and superintendents answered research questions during 21 interviews, with their consent to record the conversations. At Cruzeiro, nine out of ten 10 respondents occupied these positions. The content analysis followed the model of Bardin (2002) due to its qualitative nature. At Internacional, nine out of eleven respondents had formal positions in the strategic apex and middle line.

\section{DATA ANALYSIS}

Cruzeiro and Internacional have similarities that favor a direct comparison of their performances. Both clubs have an equivalent size of fan bases, Cruzeiro with 6.2 million supporters, 
while Internacional has 5.6 million (LANCE-IBOPE, 2014). In 2002, their annual revenues were BRL 41.7 million and BRL 24.0 million, respectively. Their option towards professionalization was motivated by sportive challenges, changes to the Pelé Law and market opportunities.

The paper starts the data analysis presenting the strategy from each club and its long-term financial implications. It follows with the structural changes implemented by both clubs, its similarities and differences. The organizational context at Cruzeiro and Internacional describes the circumstances that affected their presidents' choices. Next, it summarizes the professionalization

processes and strategy practices of each club. Then, it proceeds to examine the implications of strategy, structure and professionalization on the clubs' sport and financial performances, comparing them with each other and with the market.

\section{STRATEGY}

The changes of the football industry in the early 2000's reduced the dependency of clubs on ticket sales by generating new sources of revenues. Besides the attendance at the stadium, the match day produced an increasing flow of revenues through the broadcasting rights. The brandrelated businesses such as sponsorship, the club's image rights, merchandising and licensing became the focus to increase revenues. The globalization of the sport expanded players' negotiation with foreign clubs.

Figure 1 shows the growth of revenues of the 20 biggest Brazilian clubs between 2003 and 2012 (SOMOGGI, 2015), which attained a 378\% increase, a trend that was followed in different ways by Cruzeiro (+130\%) and Internacional, (+959\%). By 2012, the 20 biggest clubs had a total revenue of BRL 3.2 billion, Cruzeiro with BRL 120.4 million (13 ${ }^{\text {th }}$ position), and Internacional with BRL 252.9 million ( $3^{\text {rd }}$ position).

The interview with Cruzeiro's top managers revealed that its strategy was clearly designed around the football season, which was the most important change related to the club's strategy during this period. Its practice was to formalize short-term plans in other areas of the club that clearly acted as a support to football and were compelled to change plans in a short time.

At Internacional, the most significant reported changes were, first, the institutionalization of the club's strategy through the formalization of short and long-term plans, integrating its political and executive spheres to minimize the effects of political transitions upon the club's management. Due to the political diversity of its Deliberative Council (DC) and the biennial mandates, the club's directors feared that management periodical changes would jeopardize the progress of the club. To avoid it, Internacional adopted the practice of long-term strategic planning and implemented it with the collaboration of representatives of all levels and political movements. The DC had to approve the strategic planning to legitimize it during any given period, regardless of the political movement 


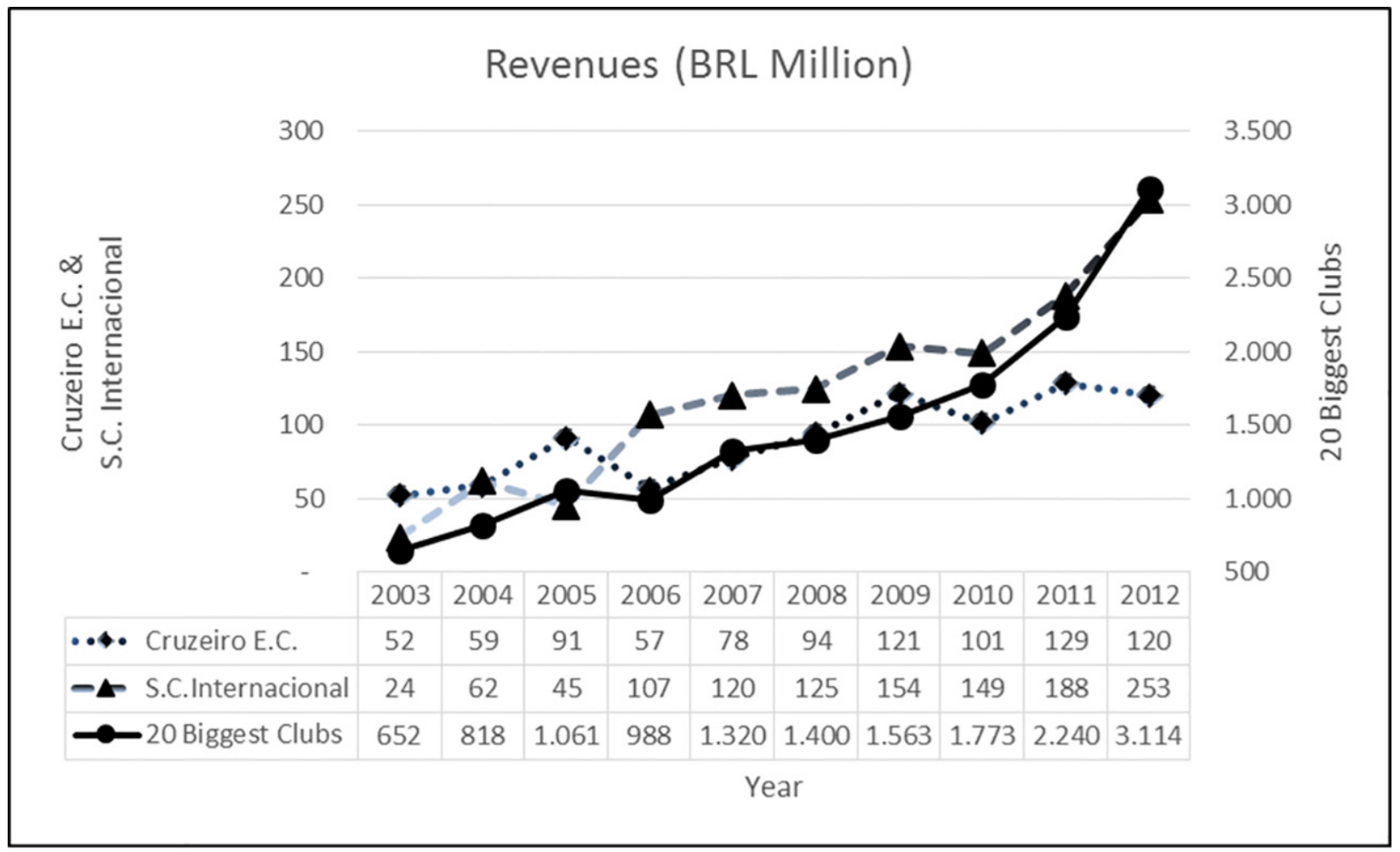

Source: Cruzeiro and Internacional annual reports; Somoggi (2015).

Figure 1. Evolution of football clubs revenues, 2003-2012.

in charge of the club. Second, the club's strategy counted on the participation of employees and managers from all areas of the club in the planning formulation and implementation, reducing centralization from its leaders. This procedure facilitated the engagement of the club's staff around the adopted strategy and gave vice-presidencies greater long-term projects autonomy.

The analysis of each club's strategy in response to the early 2000's changing environment suggests that Cruzeiro's goal was to improve its positioning through playing performance, following the priorities of each season. Due to the Brazilian industry profile, the club's conduct in face of strong competitors was to try maximizing playing success in search of differentiation, a behavior in accordance with the positioning approach from Porter (1980). Internacional seems to have reacted to the options and constraints imposed by the market by looking to improve the core competencies of its entire organization. Its engagement in the club's strategy formulation and implementation is in line with the approach proposed by Whittington (1996), showing a concern with the improvement of the practical competence of managers as strategists, which has empowered the organization in regards to the prior political prominence.

The football clubs are influenced by the pursuit of a virtuous circle. Sporting success increases revenues allowing the club to spend more with talented players to achieve further sporting success (GERRARD, 2005). The analysis of revenues from Cruzeiro and Internacional suggest that their marketing departments followed different paths. 
Figure 2 shows the evolution of Cruzeiro's sources of revenues. From 2005 to 2012, the player transfers income was reduced from BRL 56.7 million to BRL 23.6 million. This indicates a move from the players market (62\% of the total income in 2005 ) to the consumers market (stadiumbased, broadcasting and commercial revenues), which has increased its share from $38 \%$ (2005) to $80 \%$ (2012). Broadcasting revenue was the main responsible for such a change, increasing from BRL 17.1 million (2005) to BRL 52.0 million (2012). The commercial revenues also presented a relevant increase from BRL 7.3 million to BRL 21.3 million during the period, followed by match day income, moving from BRL 10.1 million to BRL 23.5 million.

In the case of Internacional, Figure 3 indicates that the growth achieved in the period, additional BRL 207.5 million, came from all sources of revenues. Broadcasting led the increase, with a BRL 74.2 million improvement. Player transfers followed with additional BRL 62.7 million. Match day comes next with extra BRL 41.4 million (fans membership included). Commercial revenues accounted an expansion of BRL 29.2 million. In general terms, the live event business (stadium-based revenues and broadcasting) kept stable at 55\% share of the total annual income, while commercial and player transfers businesses responded by the remaining $45 \%$ of the revenues. These figures suggest that the growth effort was distributed throughout the organization.

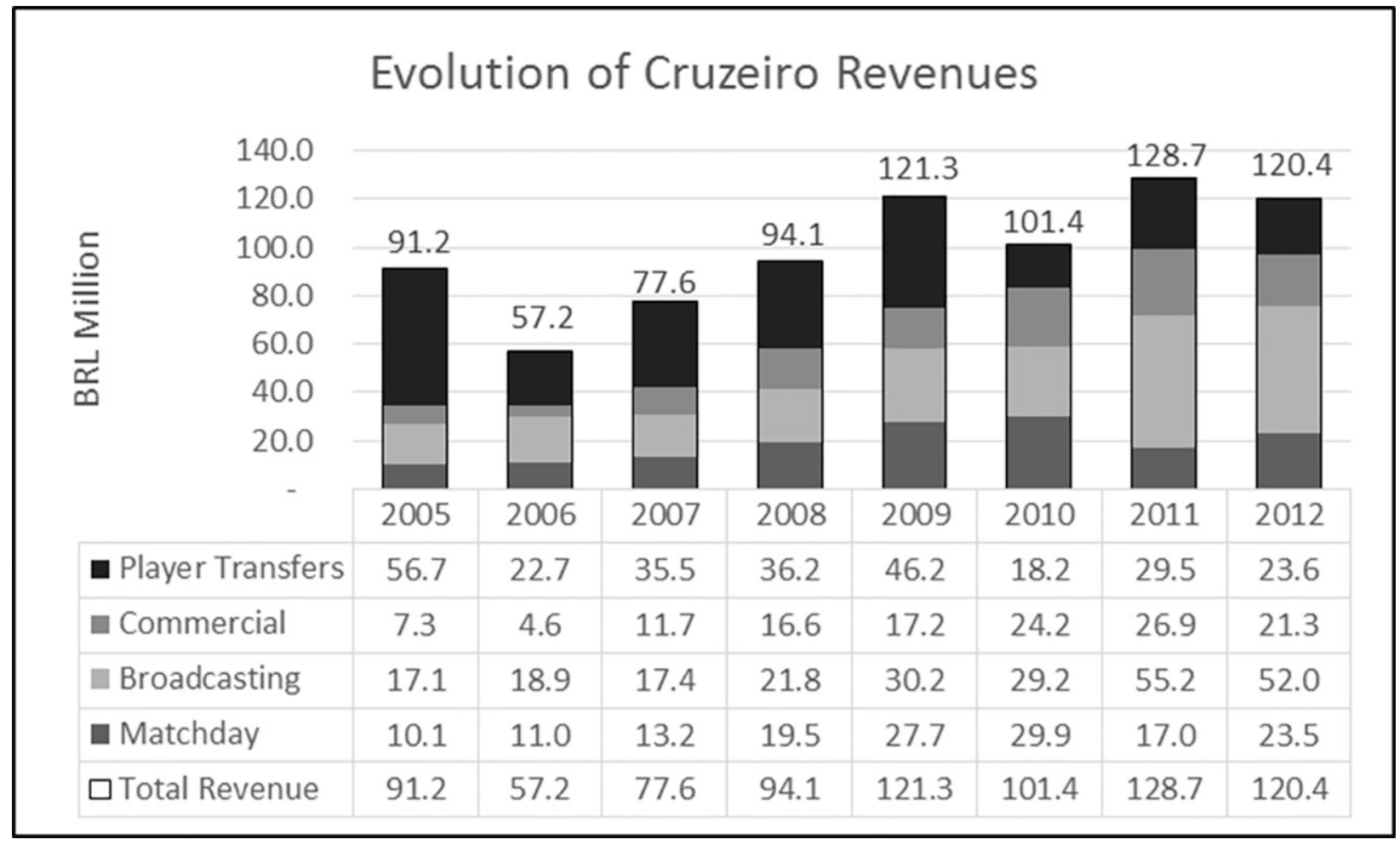

Source: Cruzeiro annual reports.

Note: The financial statements started discriminating revenues by source of origin in 2005 .

Figure 2. Evolution of Cruzeiro revenues, 2005-2012. 


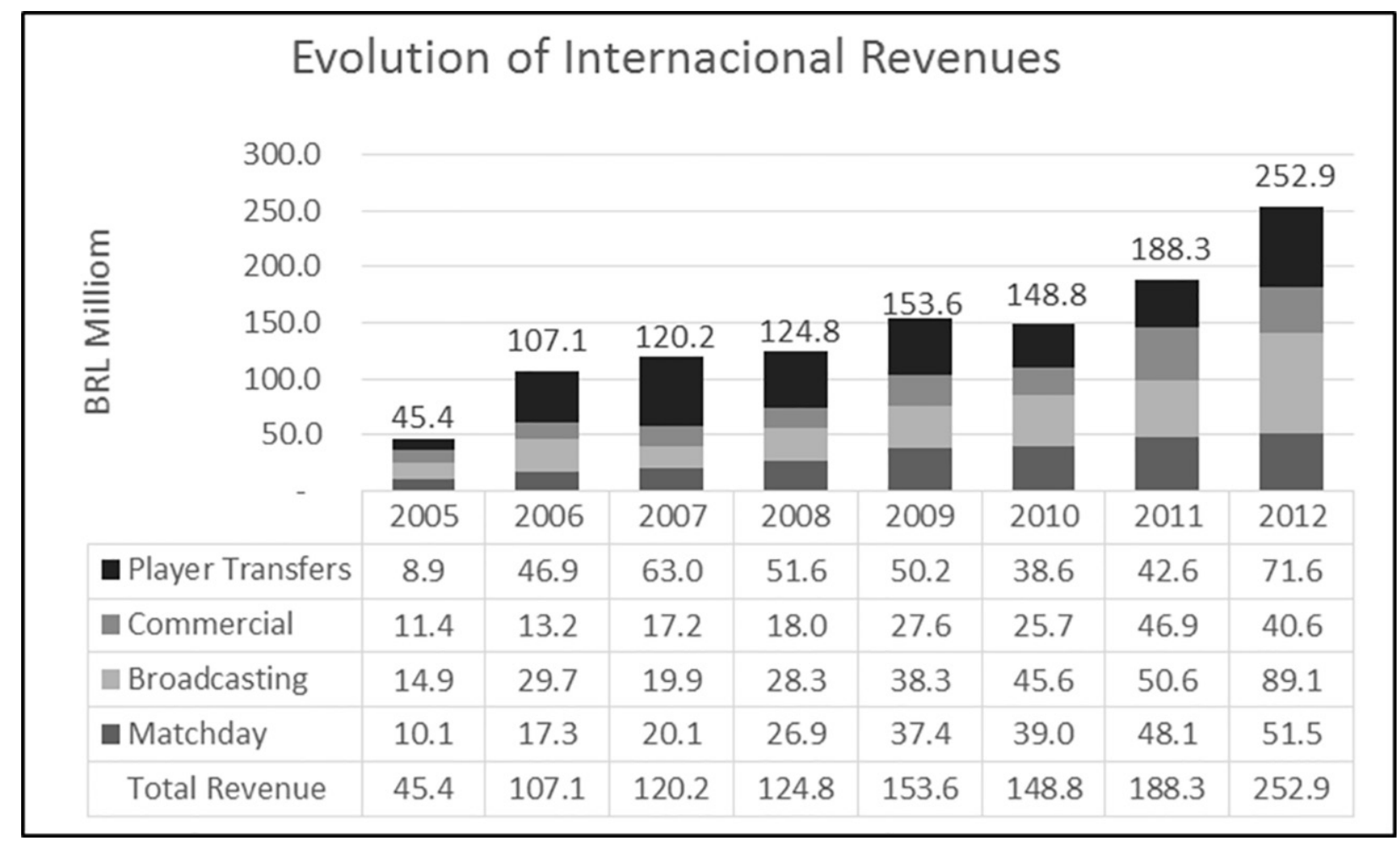

Source: Internacional annual reports.

Note: The financial statements started discriminating revenues by source of origin in 2005 .

Figure 3. Evolution of Internacional's revenues, 2005-2012.

Commercial business, however, reduced its share, from $25 \%$ to $16 \%$, in comparison with player transfers, which increased from 20\% (2005) to $28 \%$ of revenues in 2012.

The comparison of the revenues evolution between the clubs emphasizes that while Cruzeiro, through its positioning strategy (PORTER, 1980, 1991), subdued the club to the market conditions, the approach of exploiting its resource-capability combinations (WERNERFELT, 1984; BARNEY, 1991) from Internacional has produced greater benefits allowing the club to outperform the market's growth.

\section{STRUCTURE}

Cruzeiro and Internacional have simplified their organizational structures through professionalization. At Cruzeiro, a statutory reform at the end of the 90 s reduced the number of vice-presidencies from eight to two and redistributed the other positions among directors and superintendents. Internacional reduced the number of vice-presidencies from ten to four. In both cases, the changes concentrated the power in the hands of fewer people to improve decision-making efficiency and to reduce potential political conflicts. Table 1 lists the presidents that led the clubs and developed their strategies during the period under study. 
Table 1. List of presidents and periods of mandates.

\begin{tabular}{lccc}
\hline Cruzeiro & Mandate & Internacional & Mandate \\
\hline Zezé Perrella & $1995-2002$ & & \\
Alvimar Perrella & $2003-2008$ & Fernando Carvalho & $2003-2006$ \\
Zezé Perrella & $2009-2011$ & Vitório Pirffero & $2007-2010$ \\
Gilvan Tavares & 2012 & Giovanni Luigi & $2011-2014$ \\
\hline
\end{tabular}

Source: Cruzeiro and Internacional annual reports.

Cruzeiro and Internacional implemented their organizational adjustments to professionalize their structure by adopting some common actions: 1) the redesign of the middle line to accommodate salaried and fully dedicated professionals organized into functional departments in replacement of volunteer workers; 2) the increase of staff at the operational core to incorporate new functions; 3 ) the use of electronic data systems to favor the integration and coordination of activities with productivity improvement; 4) the replacement of volunteer consultants by contracted ones; 5) the centralization of the club's structure, increasing the vertical specialization (Internacional) or keeping it high (Cruzeiro). Appendices 1 and 2 present the evolution of their hierarchy.

Cruzeiro created a counseling board of directors to integrate its middle line with the initial objective to improve the interaction between different areas and inform the president about the operation of the club. However, it was reported that the informal relationship with the president prevented such integration to be more effective. The physical separation between the club's headquarters and the training centers was a concern that contributed to the use of electronic data systems, such as ERP (Electronic Resource Planning) and EDM (Electronic Document Management). The horizontal specialization increased.

At Internacional, the new middle line arrangement gave priority to areas that generated revenue or were indispensable to the football activity. The quality department took the role of formalizing the club's internal processes. The horizontal specialization decreased. The General Assembly, formally composed by all club's members, grew significantly and dispersed the power of the club to a greater number of persons. The club's marketing department was empowered obtaining status and stability under the management of the same executive director during the whole period of analysis. The club's representatives consider the increase of fans membership achieved through this department as a sign of Internacional's democratization.

These organizational changes suggest that the early 2000's market context produced a misfit of both clubs' structures and contingencies (DONALDSON, 1999), affecting their performances. Cruzeiro's reaction indicates a focus on internal processes towards their efficiency improvement, as exemplified by the implementation of an ERP and the concern with the communication between the departments and the president. Internacional, by its turn, seems to have prioritized the deployment 
of its resources and capabilities, including its supporters' loyalty through marketing initiatives, to achieve a superior growth (WERNERFELT, 1984; BARNEY, 1991).

\section{ORGANIZATIONAL CONTEXT}

\section{Cruzeiro}

The structural changes implemented by Cruzeiro were the result of the entrepreneurial approach of its presidents. Despite the lack of formalization of the decisions that triggered these changes, the interviews showed that the political cohesion in the Political Council and the satisfaction of fans with the titles conquered by the club legitimized these presidents' resolutions. Its organizational complexity increased and became more bureaucratic. The intervention of volunteer (political) leaders decreased in the Board of Directors, showing that rational processes began to prevail over political power. In the middle line, the creation of fully integrated functional departments with staffs of salaried specialized professionals, promoted greater coordination and control of the club's operating core, allowing the directors to be expeditious and more stable in their support to the vicepresidency of Football. In addition, the club's decision-making process gained efficiency with the elimination of political positions on several areas of the club.

The entrepreneurial profile of skilled negotiators of the Perrella brothers seems to have outlined the role of the presidency and other departments. The consequence of such approach was an increased dependence on the club's playing results, therefore conditioning the scope of its managerial practice.

\section{Internacional}

Mr. Carvalho and his successor, Mr. Piffero, formulated a strategy contemplating the long-term objectives to overcome the club's financial difficulties and increase its competitiveness to achieve stability. Strategy implementation implied relevant changes in the club's structure. Even though some modifications would replicate solutions typically found in profit-oriented organizations, the club's executive management refused such model based on the assumption that preserving the club's identity was mandatory to its development. Moreover, there were statutory and fiscal constraints that required innovative solutions to overcome informality from volunteer work, to empower fewer vice-presidents, to formalize the remuneration of upper management and their staff without breaking the nonprofit regulation of football clubs. Internacional's organization gained complexity with specialized teams, fully dedicated salaried professionals in key-areas, and formal processes. Besides involving the entire organization in the strategy formulation, the respondents emphasized that the engagement of the DC was necessary to guarantee its implementation and 
to assure its continuity. They said that it was a self-preservation maneuver. For them, it was something indispensable to improve the club's competitiveness, especially against bigger Brazilian competitors from the states of São Paulo and Rio de Janeiro. Regardless of the positive results achieved between 2003 and 2010, the management believed that complementary structural changes were necessary for functional improvement.

The professionalization of Internacional redesigned the relationship between the club's political and technical areas. Politics was restricted to the DC as much as possible. The management improved its decision-making efficiency and its organizational control through a modified structure composed by a leaner vice-presidency and fully dedicated staff of professionals working in accordance to integrated and rational processes with increased productivity.

\section{PROFESSIONALIZATION AND STRATEGY PRACTICE}

The 1990s had a different influence in the objectives and actions adopted by Cruzeiro and Internacional in the following decade. Cruzeiro conquered 17 different championships during those years, including the Libertadores Cup, the 2003 Brazilian cup and the national championship. Internacional, by its turn, won only four state championships and one Brazilian cup. In 1999 and in 2002, the club was very close to relegation to the second division. Therefore, in the beginning of the 2000s, Cruzeiro counted on the political support from its DC and fans. Internacional faced the opposite situation, the dissatisfaction of its DC and supporters.

Professionalization at Cruzeiro aimed the political consolidation of its president's group, the improvement of management control and sports competitiveness. At Internacional, its objective was to overcome financial difficulties, improve the club's competitiveness and reduce its vulnerability to periodic political changes.

Both clubs, due to football statutory constraints, needed mediation between their political and technical spheres. Their different contexts contributed to distinct approaches regarding this issue. Cruzeiro's president, Mr. José Perrella, chose to centralize the mediation of political and technical spheres and to personify the agreements regarding the club's strategy. With the approval provided by a good sportive performance, political support and a stable financial situation during his term of office, the president stood as the foundation around which the club conceived and implemented its strategy. The Perrella brothers embodied the visionary leader, which is typical of the Entrepreneurial Scholl described by Mintzberg, Ahlstrand and Lampel (2005). At Internacional, Mr. Carvalho chose to formalize the agreements between the political and technical spheres through the strategy formulation and its implementation, which contemplated the professionalization process. A major change of direction by the club was necessary to gain competitiveness and to achieve stability. His approach was to do it through a straight and decentralized way, requiring prior and formal 
involvement of directors, political and social members, and professionals from different areas. The involvement of the entire executive management, various departments and the DC was permanent in order to adjust the strategy and its implementation as the long-term plan unfolded, which characterized the configuration strategy model (MINTZBERG, AHLSTRAND, LAMPEL, 2005).

Cruzeiro and Internacional made similar structural changes due to professionalization. Both clubs reduced the number of political positions on the executive management to concentrate power, reduce conflicts and increase the decision-making efficiency. At the middle line, they hired fully dedicated professionals in key areas, leaving less relevant activities to volunteers and political positions. There was a division of work, increasing the degree of organizational coordination and integration. The formalization of jobs and processes, in accordance to the professionalization concept proposed by Shilbury and Ferkins (2011) and Dowling et al. (2014), improved the overall management control of clubs' activities.

\section{COMPETITIVENESS}

\section{Sporting performance}

Sporting success is the major goal of most Brazilian football clubs, instead of profit. Winning championships and the coveted cup has an important impact upon the fans and the media, enhancing the club's brand value. Table 2 shows the ranking of Brazilian teams according to the quantity of football cups conquered between 2003 and 2012. Cruzeiro and Internacional are ranked third and first place, respectively. The ranking does not take into account any relative importance that international, national and regional cups might have before the eyes of football stakeholders. When comparing their performances, some aspects regarding their sporting strategies are worth mentioning. Both clubs give emphasis to regional championships, where their fan base is concentrated. Cruzeiro won six out of twelve cups competed and Internacional won seven.

Outside their home states, Cruzeiro seems to prioritize national championships whereas Internacional seems to give preference to the international tournaments. From its eight cups, Cruzeiro won two of them in national competitions. Internacional won seven of its fourteen cups in international competitions. The year of 2003 was remarkable for Cruzeiro, when it won the state cup, Brazil's cup and the Brazilian Championship. Internacional had 2006 as its best year, winning the Libertadores and the Fifa World Club cups.

When comparing the performance of both teams in the Brazilian Championship, it becomes apparent that similar quantities of victories may lead to different final league positions. Figures 4 and 5 show the performance of the clubs in terms of goals scored, quantity of wins and the final league position. 


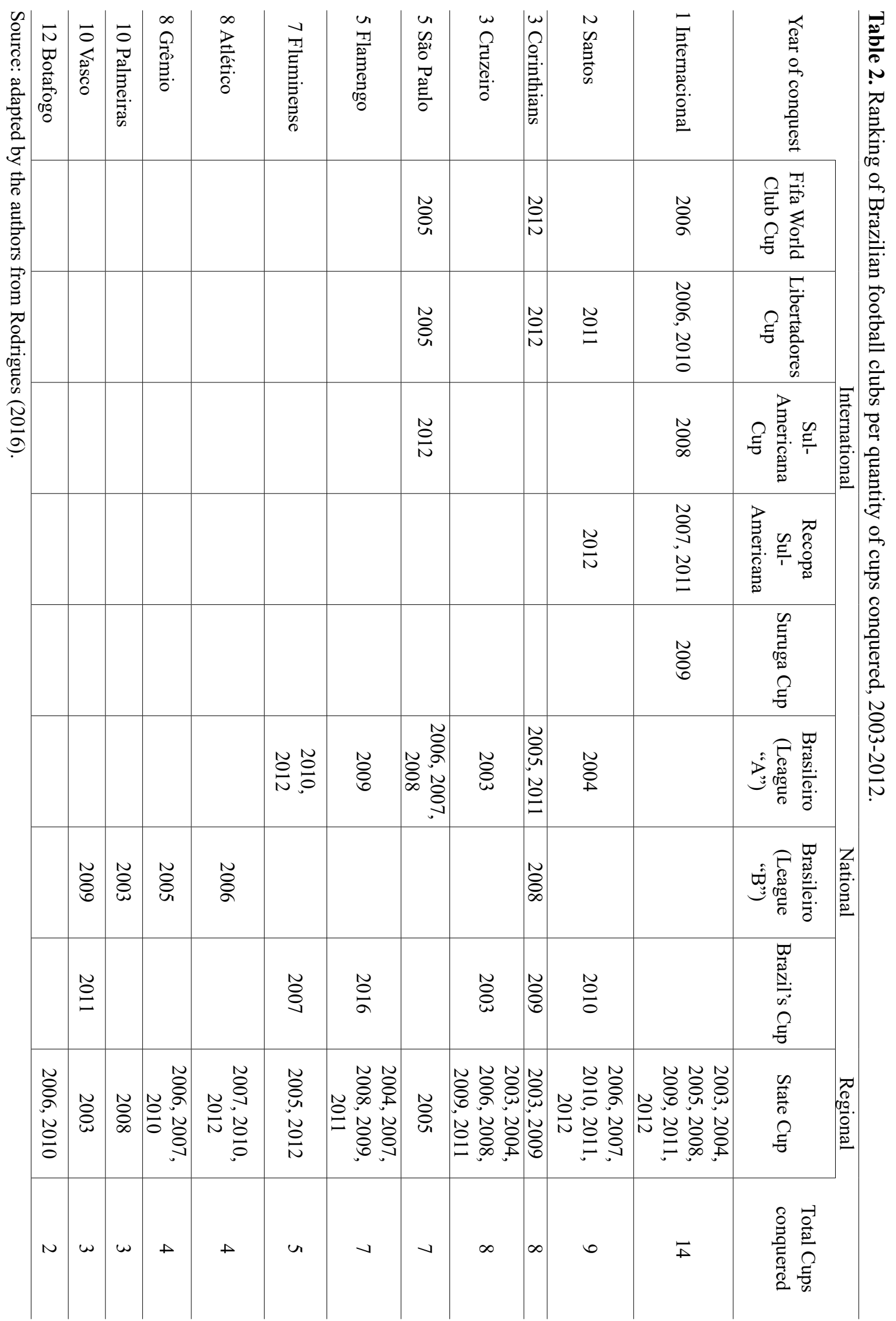




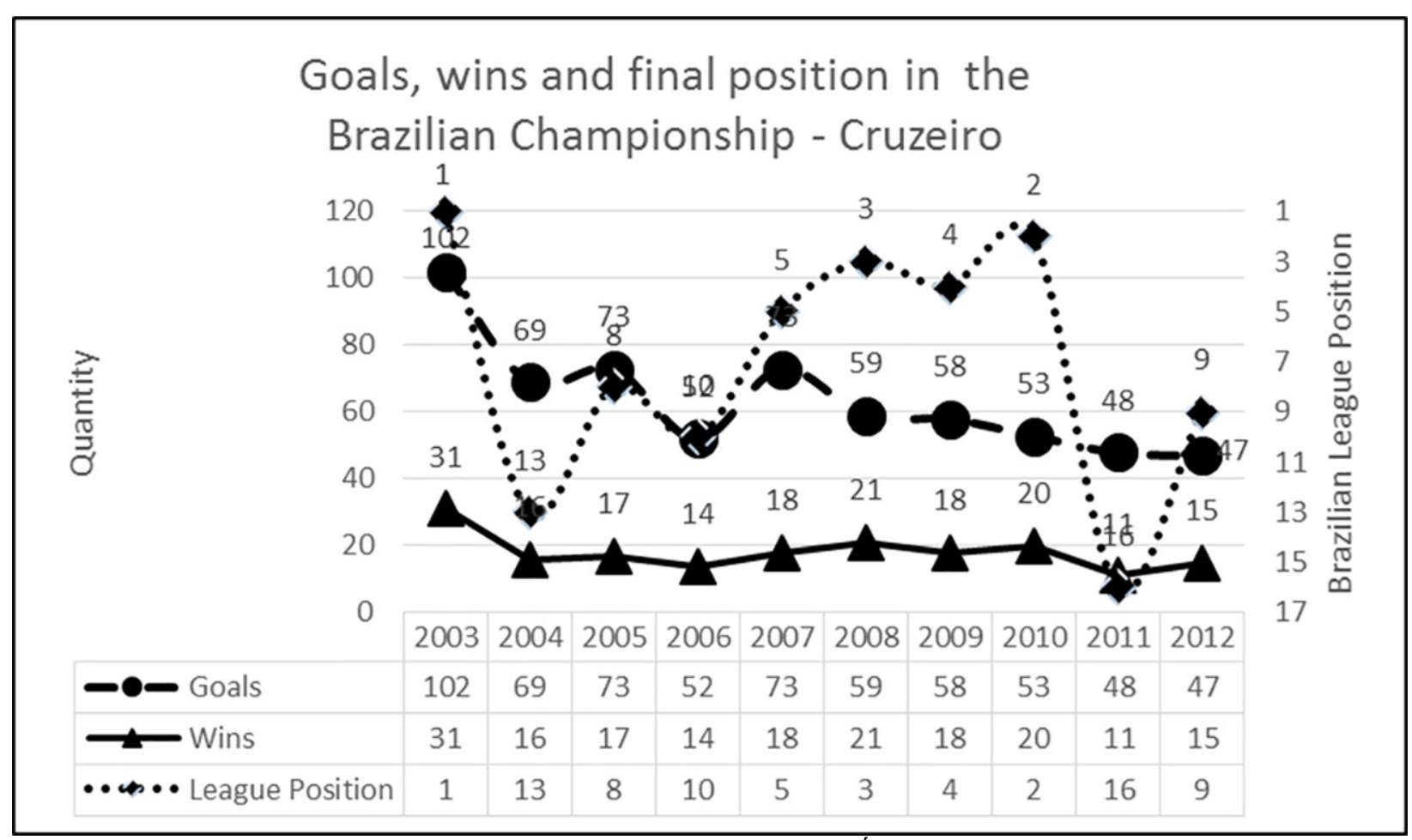

Source: graph adapted from Kase et al. (2006), statistics from Bola na Área (2015).

Figure 4. Sports performance of Cruzeiro in the Brazilian Championship, 2003-2012.

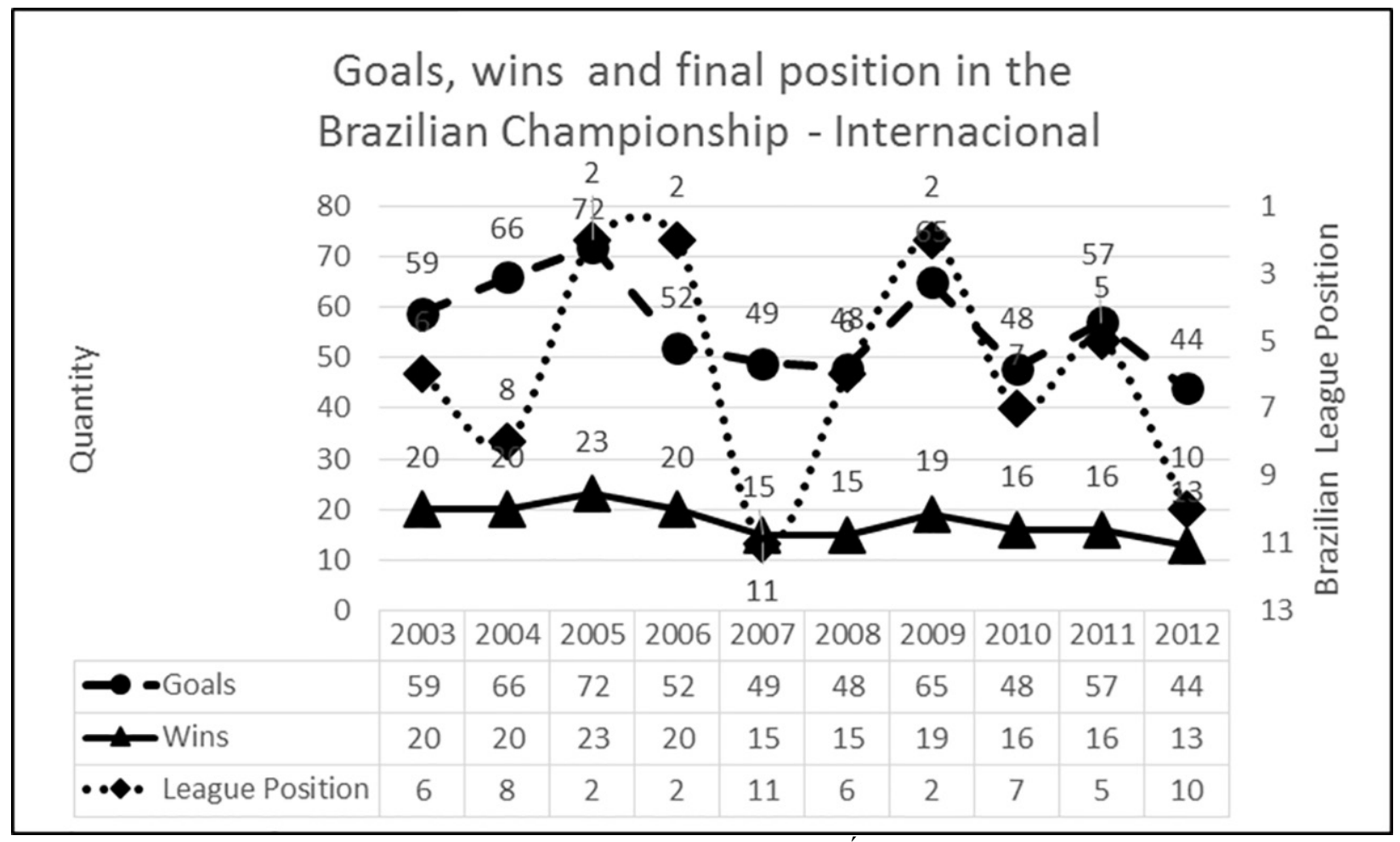

Source: graph adapted from Kase et al. (2006), statistics from Bola na Área (2015).

Figure 5. Sports performance of Internacional in the Brazilian Championship, 2003-2012 
From 2003 to 2012, Cruzeiro and Internacional competed in 400 matches each in the Brazilian Championship. Cruzeiro scored 634 goals, 13\% above the 560 goals scored by Internacional. Even with this favorable statistics, Cruzeiro won 181 times, a $45 \%$ success ratio, versus 171 wins by Internacional, a 44\% success ratio. In terms of average final position, Cruzeiro got the seventh rank against the sixth position by Internacional. The best year for Cruzeiro was 2003, with a 67\% win ratio and the first final positon; the worst was 2011, with $29 \%$ wins and the $16^{\text {th }}$ final position. Internacional had its best year in 2005, presenting a 55\% win ratio; 2007 was the worst year, when it achieved an $11^{\text {th }}$ final position with a $39 \%$ win ratio.

\section{Financial performance}

The financial strength of football club allows them to hire successful players and to develop home-grown talent through youth development schools. Figure 1 shows a period rich in opportunities for growth. The 20 biggest clubs in the country jumped their total revenue from BRL 652 million to BRL 3.1 billion ( $+378 \%$ ). Figure 6 compares the performance of Cruzeiro and Internacional to the evolution of this group's turnover. Cruzeiro grew 130\% during the period; Internacional, $+959 \%$. By taking the 20 biggest clubs as reference, Cruzeiro underperformed its competitors by $52 \%$, while Internacional outperformed them by $122 \%$.

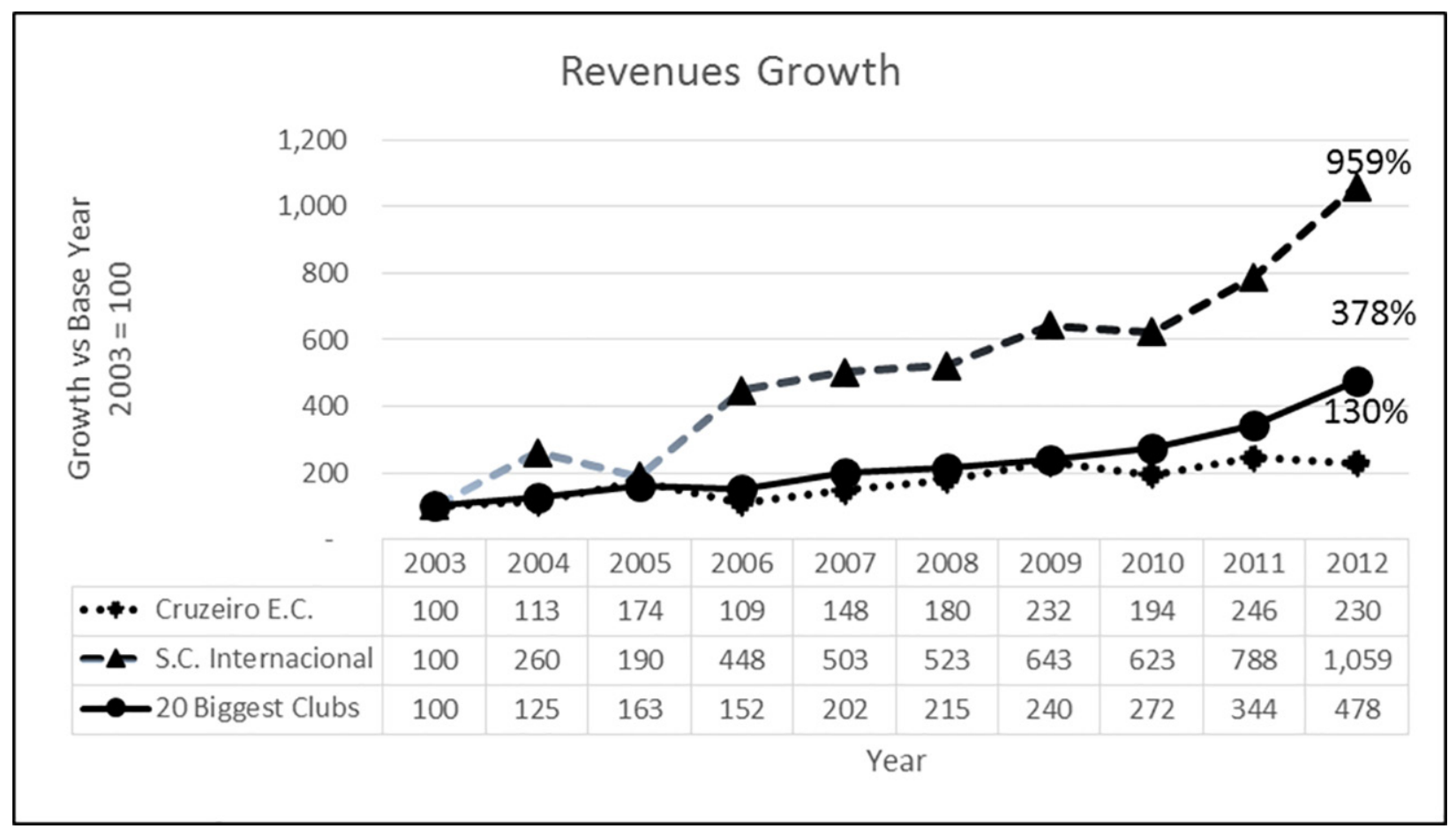

Source: Cruzeiro and Internacional's annual reports; Somoggi (2015).

Figure 6. Growth of football revenues, 2003-2012. 
From June-2010 until February-2013, the "Mineirão" stadium was closed for renovation works for the 2014 Fifa World Cup and Cruzeiro had to transfer its local matches to a smaller stadium located $70 \mathrm{~km}$ away from Belo Horizonte. This fact might explain part of the lack of growth of its revenues between 2010 and 2012. However, the performance of Internacional's revenues since 2003 suggests that the club had an advantage over its competitors.

The sports performance of both clubs gives another hint of their strategic approach and corresponding outcomes. Cruzeiro's goals scored were 13\% higher than Internacional's and its win ratio was slightly better, $45 \%$ against $44 \%$. Despite these statistics, Internacional showed a revenue growth 4.6 times higher than Cruzeiro along the period (959\% vs. 130\%). Based on that, we may infer that while Cruzeiro followed the market practices, looking for differentiation through playing success (PORTER, 1980, 1991), Internacional produced instead a higher value from its resources through innovative initiatives that were not imitated by its competitors in the short term, achieving a better fit between the entire club's organization and its environment (DONALDSON, 1999; WERNERFELT, 1984; BARNEY, 1991, 1995).

\section{Allegiance resources}

In 2004, Mr. Fernando Carvalho reformulated Internacional's strategic planning to prepare the club for its $100^{\text {th }}$ anniversary in 2009. Among the various long-term objectives that were set, the increase of alternative revenues was a priority under the responsibility of the Marketing department. Figure 7 presents the evolution of fan membership, both in quantity and in revenue. When comparing this flow of money with Figure 5, it becomes apparent that this sort of cash flow is not influenced by the club's performance on the field. Cruzeiro's membership (not plotted in Fig. 7), according to the information available, had 7,000 fans in 2008 (PLACAR, 2008) and 41,152 fans in 2012 (BARBOSA, 2013).

\section{Maximization of playing success under no breakeven constraint}

Football clubs in Brazil are nonprofit legal entities operating with the objective of maximizing playing success and no formal external constraints to achieve breakeven results. This context leads to an escalation of financial debts, past due taxes and social charges. Table 3 presents a summary of the income statements of Cruzeiro and Internacional for the year of 2012 and the 2003-2012 period.

Cruzeiro's gross revenues reached BRL 120.4 million in 2012, 130\% above 2003 revenues (fig. 1; fig. 6), but with a net loss of BRL 31 million. When comparing the year with the cumulative football costs, it is apparent that football costs are increasing above revenue growth (87\% of year's net revenue vs. $77 \%$ accumulated costs). Administrative and commercial expenses, $23 \%$ both in 2012 and in the 2003-2012 period, suggests that the club is not gaining any scale benefit from its 


\section{Evolution of Fan Memberships - Revenues (BRL Million) and Quantities $(1,000)$}

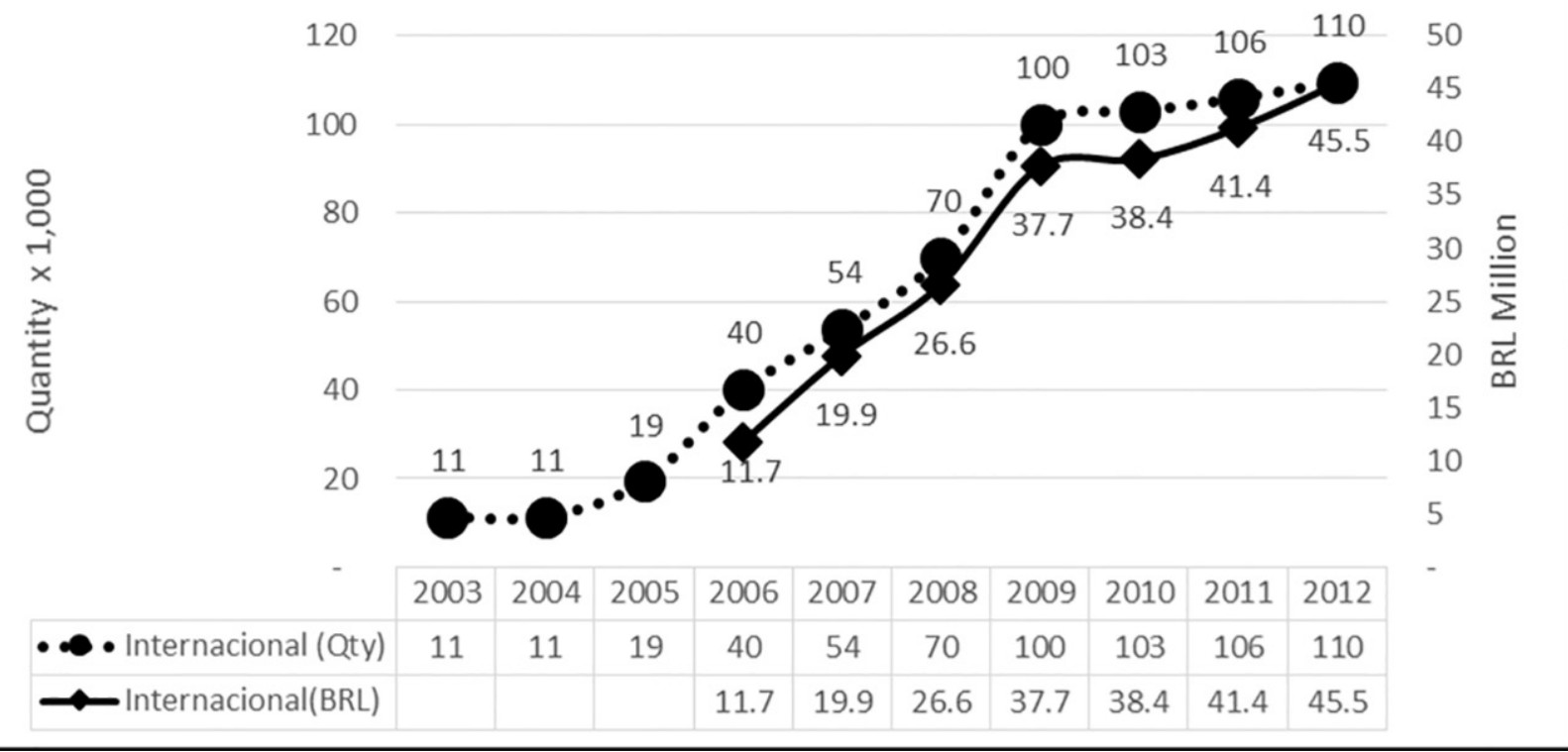

Source: Internacional internal reports, 2003-2009; Barbosa (2013); Silveira; Cardoso (2014).

Figure 7. Evolution of revenues and quantities of fan memberships, 2003-2012.

Table 3. Income statement summary, Cruzeiro and Internacional, 2003-2012.

\begin{tabular}{|c|c|c|c|c|c|c|c|c|}
\hline & \multicolumn{4}{|c|}{ Cruzeiro } & \multicolumn{4}{|c|}{ Internacional } \\
\hline & \multicolumn{2}{|c|}{ Year of 2012} & \multicolumn{2}{|c|}{ Total 2003-2012 } & \multicolumn{2}{|c|}{ Year of 2012} & \multicolumn{2}{|c|}{ Total 2003-2012 } \\
\hline & $\begin{array}{c}\text { BRL } \\
\text { Million }\end{array}$ & $\%$ & $\begin{array}{c}\text { BRL } \\
\text { Million }\end{array}$ & $\%$ & $\begin{array}{l}\text { BRL } \\
\text { Million }\end{array}$ & $\%$ & $\begin{array}{c}\text { BRL } \\
\text { Million }\end{array}$ & $\%$ \\
\hline Gross Revenue & 120.4 & $108 \%$ & 903.7 & $107 \%$ & 252.9 & $122 \%$ & $1,298.9$ & $113 \%$ \\
\hline Net Revenue & 111.3 & $100 \%$ & 846.2 & $100 \%$ & 206.9 & $100 \%$ & $1,151.2$ & $100 \%$ \\
\hline Football costs & -97.2 & $-87 \%$ & -650.9 & $-77 \%$ & -159.7 & $-77 \%$ & -895.6 & $-78 \%$ \\
\hline Social \& Amateur Sports & -9.8 & $-9 \%$ & -54.3 & $-6 \%$ & 0.0 & $0 \%$ & -1.2 & $0 \%$ \\
\hline Adm\&Com expenses & -25.2 & $-23 \%$ & -198.5 & $-23 \%$ & -29.0 & $-14 \%$ & -196.0 & $-17 \%$ \\
\hline Financial Expenses & -10.2 & $-9 \%$ & -46.1 & $-5 \%$ & -7.2 & $-3 \%$ & -79.3 & $-7 \%$ \\
\hline Non operating results & 0.0 & $0 \%$ & 16.7 & $2 \%$ & 0.0 & $0 \%$ & 3.1 & $0 \%$ \\
\hline Profit/loss & -31.0 & $-28 \%$ & -86.8 & $-10 \%$ & 11.0 & $5 \%$ & -17.9 & $-2 \%$ \\
\hline Depreciation/amortization & 2.1 & $2 \%$ & 33.2 & $4 \%$ & 19.6 & $9 \%$ & 116.2 & $10 \%$ \\
\hline EBITDA & -18.7 & $-17 \%$ & -25.2 & $-3 \%$ & 37.8 & $18 \%$ & 174.5 & $15 \%$ \\
\hline
\end{tabular}

Source: Cruzeiro and Internacional's annual reports.

EBITDA: earnings before interests, taxes, depreciation and amortization. 
revenues growth. Regarding the financial expenses, they reached $9 \%$ of 2012 revenues vs. 5\% cumulative, with a clear growth trend.

Internacional's similar analysis show opposite trends: 2012 costs and expenses are relatively lower than the totals for the period; football costs, $77 \%$ vs $78 \%$; administrative and commercial expenses, $14 \%$ vs $17 \%$, a three percentage points of scale gain; financial expenses, $3 \%$ vs $7 \%, 4$ percentage points lower. Accordingly, the year net result was a BRL 11 million surplus (profit).

In 2012, Cruzeiro's loss represented $28 \%$ of its turnover while Internacional surplus (profit) reached 5\%. In a long-term perspective, Cruzeiro shows a 10\% business loss while Internacional's loss is $2 \%$. However, the comparison of both club's EBITDAs show that similar sportive performances might generate different financial outcomes. As EBITDA refers to the earnings before interests, taxes, depreciation and amortization, it measures the business capacity to generate cash to pay its operational commitments and make new investments. Between 2003 and 2012, Cruzeiro's EBITDA presented a BRL 25.2 million deficit while Internacional's presented a BRL 174.5 million surplus, representing a BRL 200 million difference.

For a better understanding of the outcomes of these differences, Table 4 shows the evolution of the clubs' indebtedness. It shows the debts and bank financing figures, renegotiated past due social charges and taxes, at the end of the years of 2003 and 2012.

Both clubs have increasing debts with banks, Cruzeiro jumping from BRL 5 million (2003) to BRL 45.5 million (2012); Internacional, increasing from BRL 9.6 million to BRL 36.8 million. The clubs also increased their debts with the government (Past due social charges \& taxes). Cruzeiro

Table 4. Evolution of indebtedness, Cruzeiro and Internacional, 2003-2012.

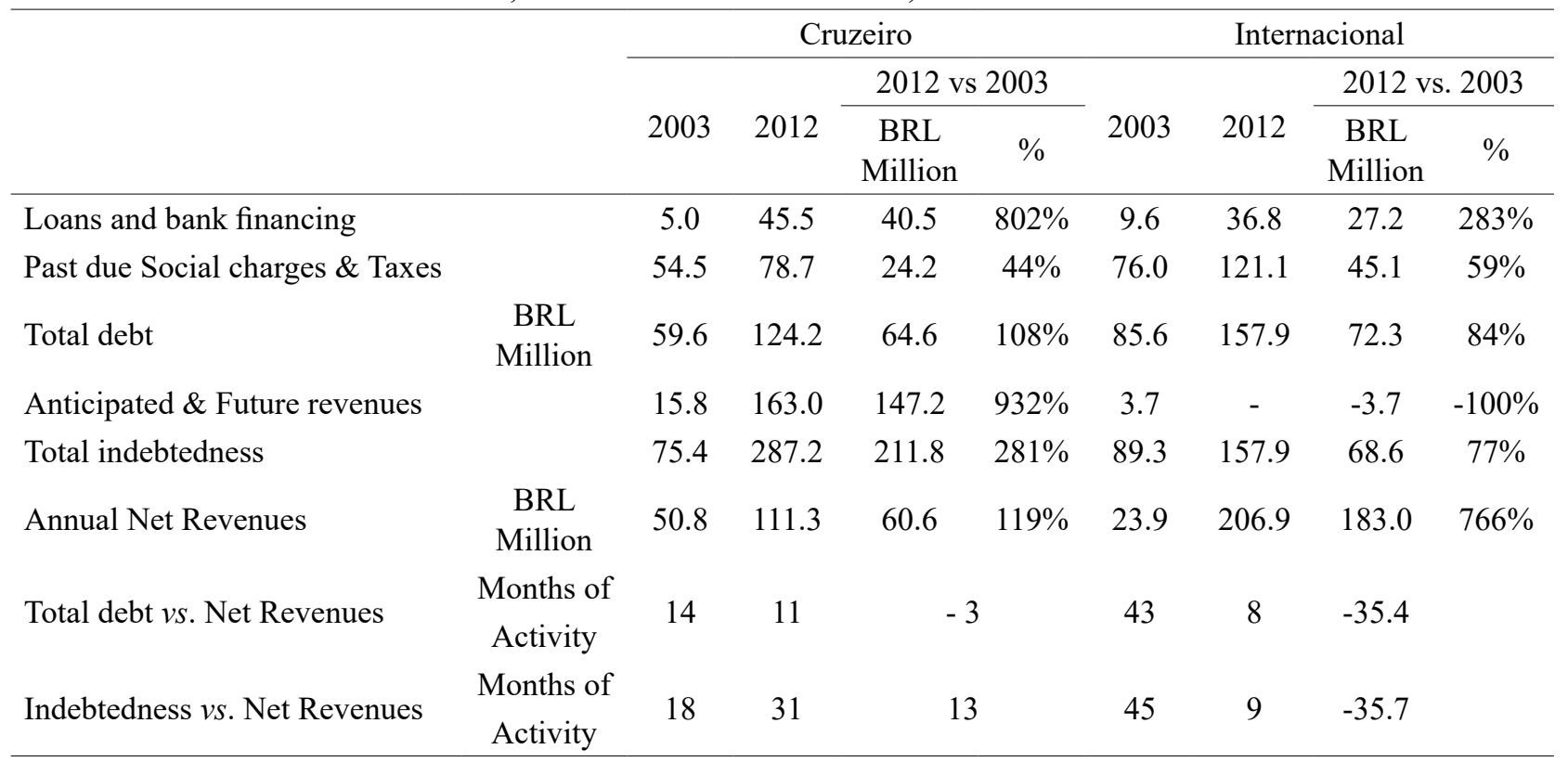

Source: Cruzeiro and Internacional's annual reports. 
moved from BRL 54.5 million to BRL 78.7 million, while Internacional went from BRL 76 million to BRL 121.1 million.

An interesting measure to evaluate the club's financial performance is to convert the total debts in a ratio corresponding to the number of months of club's activity necessary to cover the debts at the beginning and at the end of the period. Cruzeiro, for example, needed 14 months of income to cover its debts in 2003, and reduced it to 11 months in 2012. Internacional, reduced its needs from 43 months of revenues in 2003 to 8 months in 2012. Another point worth mentioning is the accounting of anticipated and future revenues registered by Cruzeiro. These amounts grew from BRL 15.8 million (2003) to BRL 163.0 million (2012), suggesting that the club might be generating cash by anticipating money from broadcasting rights. Adding this sum to the total debt, Cruzeiro would have increased its needs to cover total indebtedness from 18 months of revenue (2003) to 31 months or 2.5 years (2012).

\section{CONCLUSION}

Brazilian football clubs face unprecedented changes and opportunities with globalization, the arrival of new technologies and the imposition of new rules by the local government. During the past two decades, management professionalization was and still is a mantra used by football fans and professionals to express their vision on how to improve football practices. Revenue increase is referred to as the panacea for enhancing sports competitiveness and overcoming clubs' financial difficulties. This article sheds light on how the clubs are dealing with these challenges and to which extent strategy, structure and professionalization are being used to their benefit.

The clubs investigated have the same product, equivalent markets, fan bases and sports performance. The longitudinal study suggests that even though both clubs have adopted similar professionalization and organizational changes to boost their revenues, they differed in strategy and the way they have strategized. The configuration approach from Internacional's strategy produced a better structure-contingency fit, leading its revenues to outperform the 20 biggest clubs by $122 \%$ during the 10 year period investigated. On the other hand, the study suggests that the entrepreneurial style adopted by Cruzeiro's presidents in their strategy practice might have provoked a mismatch between the structure and its environment, making the club underperform the market by $52 \%$. The outcome was a difference of BRL 200 million in EBITDA generation, favoring Internacional in comparison to Cruzeiro, with 6 extra cups, approximately $10 \%$ less goals scored and a slightly lower win ratio. Consequently, Internacional reduced the revenue period required to cover its debts from 3.6 years to eight months while Cruzeiro reduced it from 14 to 11 months, with the anticipation of broadcasting rights and future revenues jumping from four months to 1.5 year. 
The comparison of clubs' sportive and financial performance with the 20 biggest Brazilian clubs suggests that Internacional succeeded in developing a sustained competitive advantage between 2006 and 2010, with a relevant contribution from its marketing department. Meanwhile, Cruzeiro's underperformance against the market led to estimated losses of at least BRL 60 million income during the period of analysis. One common point disclosed by the analysis, however, is that after this ten-year period both clubs might have to consider that the time has come for pivoting and changing strategy directions. Cruzeiro may confront its past playing achievements with the loss of money and debt increase to take a decision on how to proceed. Internacional, in turn, may take into account that competitors, jeopardizing its competitive advantage and its future sporting success, have finally succeeded in imitating its innovative marketing practices.

As suggested by Barney (1995), the cases of these two clubs confirm that investigating sports strategy implementation should not be done separately from a club's content of strategy or its competitive context. It also shows that professionalization and structure changes are highly dependent on strategy formulation and the strategizing process to become effective responses to organizational contingencies.

The choices of Cruzeiro and Internacional had positive effects on them during the past decade. By comparing their performances, this study highlights the impact of their strategy and structural changes, advancing the empirical knowledge about the long-term consequences of the win maximization strategy with self-imposed (or not) break-even constraints in clubs' competitiveness. If we agree with the idea that playing success in a football club depends on teamwork, the study emphasizes that it should extrapolate the pitch lines to reach the boundaries of the entire football team organization to achieve sustainable sporting success. It raises additional evidence that the investigation of clubs' financial efficiency as well as the role of boards in clubs' strategy and governance will be beneficial to the development of the sport. Further research on clubs' annual reports content is recommended to improve their quality and transparency. Finally, the development of similar studies extending the scope to additional relevant clubs is needed to assist Brazilian football in overcoming its current financial crisis. After all, management is not a game and strategy in sports does matter.

\section{REFERENCES}

AIDAR, A.C.K.; LEONCINI, M.P. Evolução do futebol e do futebol como negócio. In: AIDAR, Antônio Carlos Kfouri; LEONCINI, M.P.; OLIVEIRA, J.J. (Org.) A nova gestão do Futebol. 2.ed. Rio de Janeiro: FGV, cap.5, p.79-100. 2002.

ALBINO, J.C.A.; CARRIERI, A.P.; FIGUEIREDO, D.; SARAIVA, F.H.; BARROS, F.L.R.S. Sport Club Internacional e a constituição da identidade corporativa de "clube-empresa". Organizações \& Sociedade, v.16, n.48, p.81-100, 2009. 
AREIAS, J. H. Uma Bela Jogada: 20 anos de marketing esportivo. Rio de Janeiro: Outras Letras, 2007.

AZEVEDO, C; REBELO, A. A corrupção no futebol brasileiro. Revista Motrivivência, ano XII, n.17, p.15-45. Florianópolis: Editora UFSC, 2002.

BARDIN, L. Análise de conteúdo. Trad. Luís Antero Reto e Augusto Pinheiro. Lisboa: Edições 70, 2002.

BARNEY, J. Firm resources and sustained competitive advantage. Journal of Management, v.17, n.1, p.99-120, 1991.

BARNEY, J. Looking inside for competitive advantage. Academy of Management Executive, v.9, n.4, p.49-61, 1995.

BOLA NA ÁREA. Arquivo do futebol. Campeonato Brasileiro.

CHANDLER, A. D. Strategy and Structure: Chapters in the History of the Industrial Enterprise. Cambridge, Mass.: M.I.T. Press, 1962.

DESBORDES, M. (Org.) Marketing and football: an international perspective. Oxford: ButterworthHeinemann. 2007.

DIMITROPOULOS, P. Capital structure and corporate governance of soccer clubs: European evidence. Management Research Review. v.37, n.7, p.658-678, 2014.

DONALDSON, L. Teoria da Contingência Estrutural. In: CALDAS, M; FACHIN, R; FISCHER, T. (Orgs). Handbook de estudos organizacionais. São Paulo: Atlas, 1999.

DOWLING, M.; EDWARDS, J.; WASHINGTON, M. Understanding the concept of professionalization in sport management research. Sport Management Review, v.17, p.520-529, 2014.

FLICK, U. Uma introdução à pesquisa qualitativa. Porto Alegre: Bookman, 2004.

GARCIA-del-BARRIO, P.; SZYMANSKI, S. Goal! Profit maximization versus win maximization in soccer. Review of Industrial Organization, v.34, n.1, 2009.

GERRARD, B. Why does Manchester United keep winning on and off the field? In:ANDREWS, D. (Ed.) Manchester United: An interdisciplinary study, p.65-86. Oxford: Berg, 2005.

GONÇALVES, J.C.S.; CARVALHO, C.A. A mercantilização do futebol brasileiro: instrumentos, avanços e resistências. Cadernos EBAPE, v.4, n.2, p.1-27, 2006.

GONÇALVES, J.C.S.; SILVA, C.E. "Empresarização" e controle: o caso do Figueirense Futebol Clube. Cadernos EBAPE, v.5, n.3, p.1-16, 2007.

GRUNDY, T. Strategy and financial management in the football industry. Strategic Change, n.13, p.405-422, 2004.

HAMIL, S.; MICHIE, J.; OUGHTON, C. (Org.) The business of football: a game of two halves? Edinburgh: Mainstream Publishing, 1999.

HWANG, H; POWELL, W.W. The rationalization of charity: the influences of professionalism in the nonprofit sector. Administrative Science Quarterly, v.24, p.268-298, 2009.

KASE, K.; GÓMEZ, S.; URRUTIA, I.; OPAZO, M.; MARTI, C. Real Madrid - Barcelona: business strategy vs. sports strategy, 2000-2006. Occasional Paper, IESE, jun.2006 
LANCE-IBOPE. As maiores torcidas de futebol. Lance!: São Paulo, 2014.

LAWRENCE, P.R.; LORSCH, J.W. Differentiation and integration in complex organizations. Administrative Science Quarterly, v.12, n.1, p.1-47, 1967.

LEONCINI, M.P.; SILVA, M.T. Entendendo o futebol como um negócio: um estudo exploratório. Gestão \& Produção, v.12, n.1, p.11-23, 2005.

MINTZBERG, H. Criando organizações eficazes: estruturas em cinco configurações. São Paulo: Atlas, 1995.

MINTZBERG, H.; AHLSTRAND, B.; LAMPEL, J. Strategy safari: a guided tour through the wilds of strategic management. New York: The Free Press, 2005.

MORROW, S. Financial fair play - implications for football club financial reporting. Edinburgh: ICAS. 2014.

NASCIMENTO, J.C.H.B.; NOSSA, V.; BERNARDES, J.R.; SOUSA, W.D. A eficiência dos maiores clubes de futebol brasileiros: evidências de uma análise longitudinal no período de 2006 a 2011. Revista Contabilidade Vista \& Revista, v.26, n.2, p.137-161, 2015.

PORTER, M. Competitive strategy. Free Press, 1980.

PORTER, M. Towards a dynamic theory of strategy. Strategic Management Journal, v.12, p.95-117, 1991.

RADIC, M. Corporate governance and ownership structure of European football clubs. 2014. Proceedings of the $2^{\text {nd }}$ International OFEL Conference on Governance, Management and Entrepreneurship, 4th 5th April, Dubrovnik, Croatia, 2014.

RATTEN, V. The dynamics of sport marketing. Marketing Intelligence \& Planning, v.34, n.2, p.162-168, 2016.

RIBEIRO, Luiz (Org.). Futebol e globalização. Jundiaí: Fontoura, 2007.

RODRIGUES, M. S.; SILVA, R. C. A estrutura empresarial nos clubes de futebol. Organizações \& Sociedade, v.16, n.48, p.17-37, 2009.

RODRIGUES, R. Inter é o grande com mais títulos no século XXI. Futebol em números, 2016.

SHILBURY, D.; FERKINS, L. Professionalisation, sport governance and strategic capability. Managing Leisure, n.16, p.108-127, 2011.

SILVA, R. C. Finanças dos clubes brasileiros e valor das marcas dos 17 clubes mais valiosos do Brasil. São Paulo, SP: BDO RCS, 2012.

SLOANE, P. J. The economics of professional football revisited. Scottish Journal of Political Economy. v.62, n.1, p.1-5, 2015.

SOMOGGI, A. Finanças dos clubes brasileiros em 2014. São Paulo, 2015.

SOUZA, F. A. P.; ANGELO, C. F. O fim do passe e seu impacto sobre o desequilíbrio competitivo entre as equipes de futebol. Revista de Administração - RAUSP, v.40, n.3, p. 280-288, 2005.

VALENTE, R.; SERAFIM, M. C. Gestão esportiva: novos rumos para o futebol brasileiro. RAE Revista de Administração de Empresas, v.46, n.3, p.131-136, 2006

WERNERFELT, B. A resource based view of the firm. Strategic Management Journal, v.5, p.171180, 1984. 
WHITTINGTON, R. Strategy as practice. Long Range Planning, v.29, n.5, p.731-735, 1996.

YIN, R. K. Estudo de caso: planejamento e métodos. Porto Alegre: Bookman, 2001.

ZOUAIN, D. M.; ALVES, J. A. B.; PIERANTI, O. P. Relatório final de atividades do Fórum de Discussão Permanente de Políticas de Esporte. RAP - Revista de Administração Pública, v.40, n.4, p.731-738, 2006. 
Appendix 1. Evolution of Cruzeiro's organizational structure.

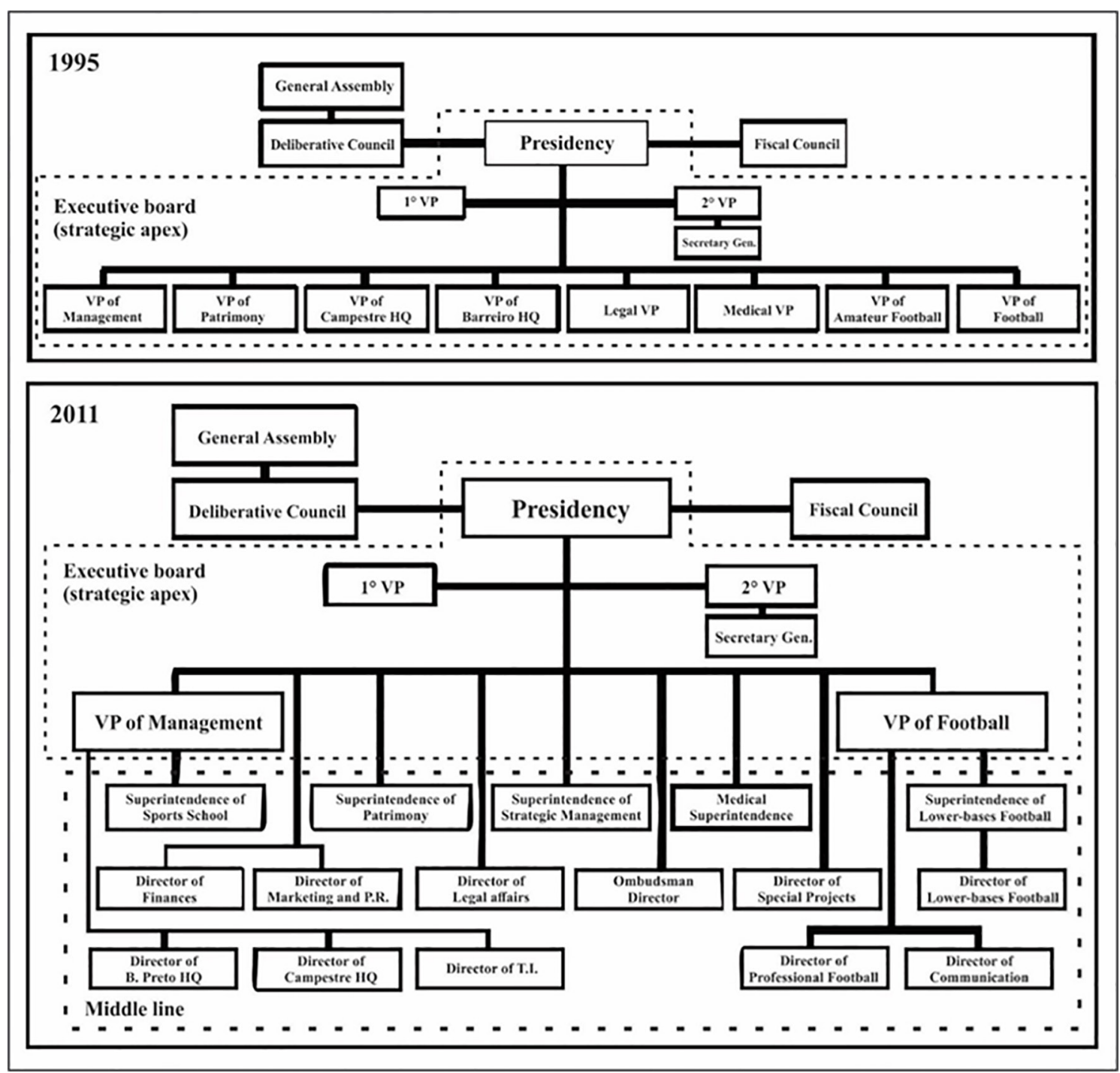

Source: Cruzeiro internal reports. 
Appendix 2. Evolution of Internacional's organizational structure.

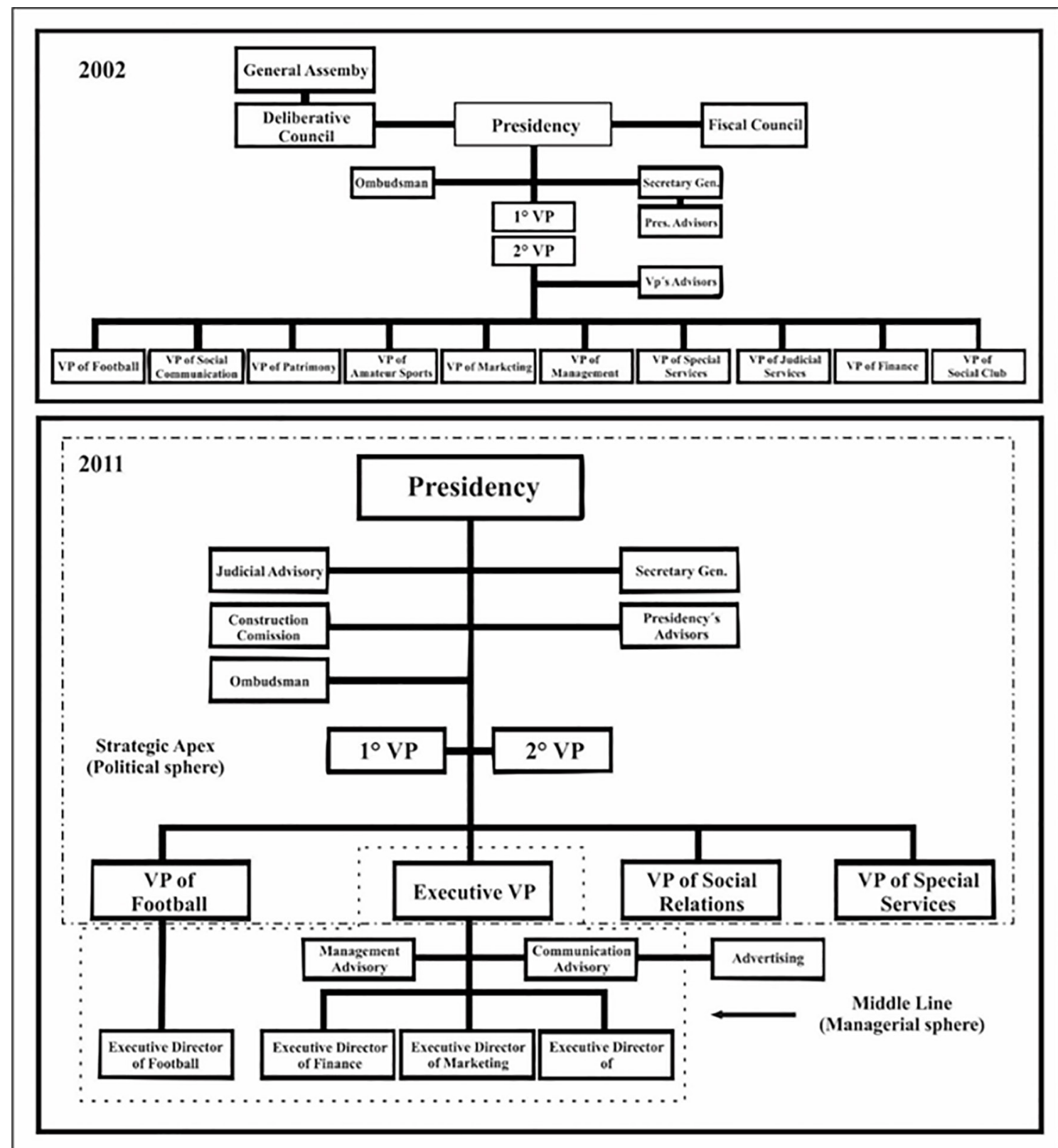

Source: Internacional internal reports. 